\title{
Early Occupations and Cultural Sequence at Moose Creek: A Late Pleistocene Site in Central Alaska
}

\author{
GEORGES A. PEARSON ${ }^{1}$
}

(Received 27 October 1998; accepted in revised form 20 May 1999)

\begin{abstract}
Early investigations at the Moose Creek site in 1979 and 1984 recovered stone tools within and below paleosol stringers dated between $8160 \pm 260{ }^{14} \mathrm{C} \mathrm{yr} \mathrm{BP}$ and $11730 \pm 250{ }^{14} \mathrm{C} \mathrm{yr} \mathrm{BP}$. Although questions remained regarding the absence of diagnostic artifacts and the validity of the radiocarbon dates obtained from soil organics, this assemblage was tentatively assigned to the Nenana complex. Excavations at the site were resumed in 1996 in hopes of solving persisting problems associated with the culture-historical positions of its components. Microstratigraphic excavation techniques identified two superimposed microblade components associated with the Denali complex. Hearth charcoal dated the deepest microblade occupation at $10500 \pm 60{ }^{14} \mathrm{C}$ yr BP, while a geological sample dated the second at $5680 \pm 50{ }^{14} \mathrm{C} \mathrm{yr} \mathrm{BP}$. The oldest microblades lay $15 \mathrm{~cm}$ above a Nenana complex occupation that contained a hearth dated at $11190 \pm 60{ }^{14} \mathrm{C}$ yr BP. Artifacts associated with this feature included a large scraper-plane, two side scrapers, a biface, an exhausted flake core, a hammerstone, and anvil stones, as well as a subtriangular point and a teardrop-shaped Chindadn point. The majority of these tools were manufactured from a large basalt cobble reduced using a bipolar technique. Subsurface testing at several localities around the site did not uncover new late Pleistocene occupations. The chronostratigraphic positions of the diagnostic artifacts found during the re-excavation support previous culturehistorical sequences observed for Nenana and Denali complexes in the region. Results from this latest research confirm that the Nenana and Denali complexes are chronologically, stratigraphically, and technologically distinct in the Nenana Valley.
\end{abstract}

Key words: Alaska, Beringia, Denali complex, Nenana complex, Paleoindians, Pleistocene

RÉSUMÉ. De premières recherches au site Moose Creek, effectuées en 1979 et 1984, ont révélé la présence d'outils de pierre situés à l'intérieur et sous des paléosols datant d'entre $8160 \pm 20$ et $11730 \pm 250$ années ${ }^{14} \mathrm{C}$ BP. Cet ensemble fut provisoirement assigné au complexe Nenana, bien que des doutes subsistaient quant à l'absence d'outils diagnostiques et à la validité des datations radiocarbones obtenues à partir de matières organiques. Néanmoins, l'identification des affiliations culturelles des objets retrouvés continuait à poser un problème. C'est donc dans le but de le résoudre que le site fut excavé de nouveau en 1996 . Des techniques d'excavation microstratigraphiques ont permis d'identifier deux occupations superposées à microlames appartenant au complexe Denali. Du charbon provenant d'un foyer permit d'obtenir la date de l'occupation à microlames la plus profonde, soit $10500 \pm 60$, alors qu'un échantillon géologique permit d'établir celle de la deuxième occupation à $5680 \pm 50$ années ${ }^{14} \mathrm{C}$ BP. Les microlames les plus anciennes reposent à quelque $15 \mathrm{~cm}$ au-dessus d'une occupation du complexe Nenana qui comptait un foyer datant de $11190 \pm 60$ années ${ }^{14} \mathrm{C}$ BP. Les artefacts reliés à cette occupation comprenaient un grand rabot, deux racloirs, un biface, un nucléus, des enclumes et des percuteurs de pierre, de même qu'une pointe triangulaire ainsi qu'une pointe Chindadn en forme de larme. La plupart de ces outils furent fabriqués à partir d'un gros galet de basalte réduit à l'aide d'une technique bipolaire. Des tests souterrains effectués à plusieurs endroits près du site n'ont pas permis de découvrir de nouvelles occupations appartenant au Pléistocène récent. Les données chronostratigraphiques associées aux objets diagnostiques trouvés lors de la dernière excavation appuient les anciennes séquences culturelles observées pour les complexes Nenana et Denali dans la région. Les résultats de cette dernière recherche confirment que les complexes Nenana et Denali sont chronologiquement, stratigraphiquement et technologiquement distincts dans la vallée du Nenana.

Mots clés: Alaska, Béringie, complexe Denali, complexe Nenana, période paléoindienne, Pléistocène

Traduit par l'auteur.

\section{INTRODUCTION}

The Moose Creek archaeological site is situated on a hilltop point near the confluence of Moose Creek and the Nenana River (Fig. 1). The site faces southwest on the eastern side of the river and is located $210 \mathrm{~m}$ above the modern floodplain on a terrace of the Nenana gravel formation (Wahrhaftig, 1958; Hoffecker, 1996). The highest known archaeological site in the region (Hoffecker, 1996), it affords a commanding view of the entire southern half of the valley.

The site was discovered in 1978 by J.F. Hoffecker and C.F. Waythomas (Hoffecker, 1982) during the North Alaska Range Early Man Project. The goal of that first survey was

\footnotetext{
${ }^{1}$ Department of Anthropology, University of Kansas, 622 Fraser Hall, Lawrence, Kansas 66045, U.S.A.; ftgap@eagle.cc.ukans.edu
}

(C) The Arctic Institute of North America 


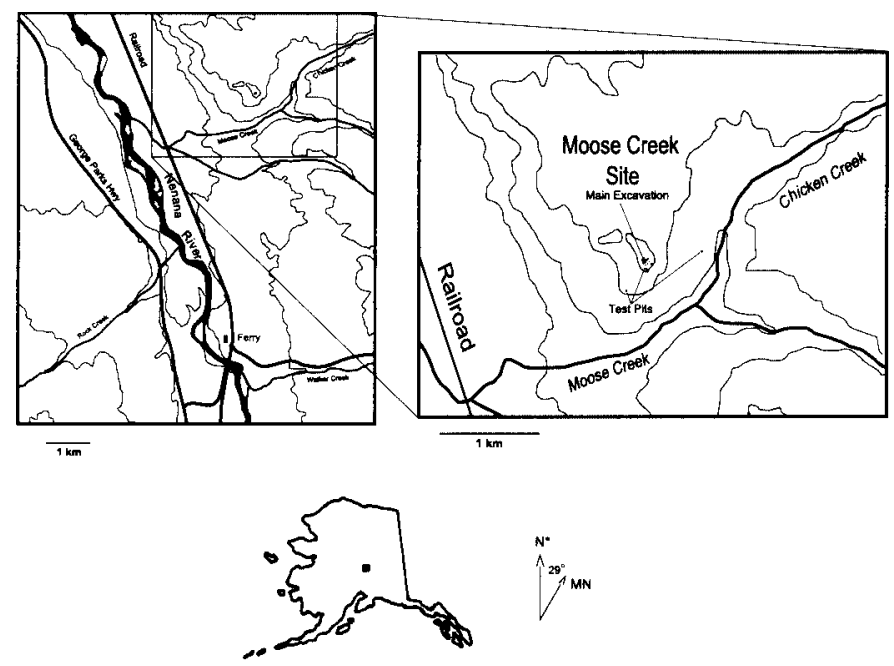

FIG. 1. Location of Moose Creek Site, Nenana Valley, Central Alaska.

to assess the extent of late Pleistocene occupations in the Nenana Valley (Hoffecker et al., 1988) folowing the discovery some years earlier of a pre $11000{ }^{14} \mathrm{C}$ yr occupation at the Dry Creek site (Holmes, 1974; Powers and Hoffecker, 1989). Small-scale excavations were carried out at Moose Creek in 1979 and 1984, totaling approximately $201 \mathrm{~m}^{2}$ units. At that time, two cultural components were identified (Hoffecker, 1985). The first contained nondiagnostic tools within and below paleosol stringers dated between $8160 \pm 260$ and $11730 \pm 250{ }^{14} \mathrm{C}$ yr BP. The second consisted of a dozen flakes and a biface fragment of undetermined Holocene age. Because there were no microblades in the lower component, it was tentatively assigned to the Nenana complex (Powers and Hoffecker, 1989; Hoffecker, 1996). However, concerns persisted regarding both the validity of associating the assemblage with the radiocarbon dates obtained from soil organics and the absence of diagnostic Nenana complex tools, such as Chindadn "points" and scraper planes similar to the ones discovered at the nearby Walker Road and Dry Creek sites (Hoffecker et al., 1993). To address these lingering problems, the Moose Creek site was re-excavated in 1996.

\section{OBJECTIVES OF THE RE-EXCAVATION}

An important aim of the 1996 re-excavation was to liberate the Moose Creek site from a state of limbo. Indeed, the perplexing absence of diagnostic tools belonging to either the Nenana or the Denali complex led many archaeologists to disregard the site, since it could not be categorized or discussed with any degree of certainty. Its apparent antiquity and the composition of its assemblage were anomalous when compared to other sites in central Alaska, suggesting that Moose Creek was perhaps an older, preNenana occupation.

The objectives of the re-excavation were fourfold. The first objective was to identify the culture-historical affiliations of the site's components through diagnostic tool types and test if the absence of such objects was due to sampling error. The second objective was to establish a reliable chronology of the site's occupations by securing radiocarbon dates using wood charcoal, preferably from hearths. Third, if the first two objectives could be fulfilled, these data would be used to confirm or refute previous chronostratigraphic sequences put forth for the Nenana and Denali complexes (Powers et al., 1983, 1990). This was especially important, since the Old World origins of these cultural assemblages are still not fully understood. Although the microblade industry characterizing the Denali complex is unquestionably related to the Upper Paleolithic Dyuktai culture of Siberia (West, 1981, 1996), the Nenana complex remains an isolate, with no convincing precursor in the Russian Far East. Moreover, chronological overlap between the Nenana complex and microblade industries from the Broken Mammoth (Yesner et al., 1999) and Swan Point (Holmes et al., 1996; Dilley, 1998) sites in the Tanana Valley hint at a possible relationship between the two cultures. This situation has suggested to some researchers that the Nenana complex may, in fact, be a technological subset of the Denali complex, thus rendering the search for the origins of the Nenana complex a moot endeavor (West, 1996). Hence, the final overall objective of the re-excavation was to ascertain the validity of these complexes in the Nenana Valley through chronological, stratigraphical, technological, and typological criteria.

\section{STRATIGRAPHY AND DEPOSITS}

The stratigraphy of the Moose Creek site is composed of seven distinct lithostratigraphic units that progressively thin and compress at the bluff's edge (Fig. 2, Table 1). Deposits consist of eolian silt and sand that vary in total thickness between 80 and $40 \mathrm{~cm}$. Of significance is the presence of two buried soil complexes (Units 2 and 5) separated by a layer of sand.

The oldest stratigraphic layer, Unit 1, is glacial outwash composed of mixed cobbles and sand. Unit 2 consists of eolian silt that contains a buried soil in its upper section. This paleosol appears as a thin discontinuous dark band within the massive, tan-coloured loess and is located just below the $5 \mathrm{~cm}$ thick silvery sand layer of Unit 3 . Unit 4 is a deposit of coarse sand averaging $25 \mathrm{~cm}$ thick. Its upper section contains a faint paleosol stringer and is weathered by leaching from the overlying acidic soils. Unit 5 is composed of bands of buried forest soils (paleo-Bw horizons) formed in sandy loam and interlaced with thin sand lenses. It averages $15 \mathrm{~cm}$ in thickness, has an undulating surface, and shows considerably more weathering and development than the modern Subarctic Brown Forest soil (Cryochrept, Unit 6) above it.

Although major disturbances (such as solifluction) were not present at Moose Creek, some microfaulting, one 


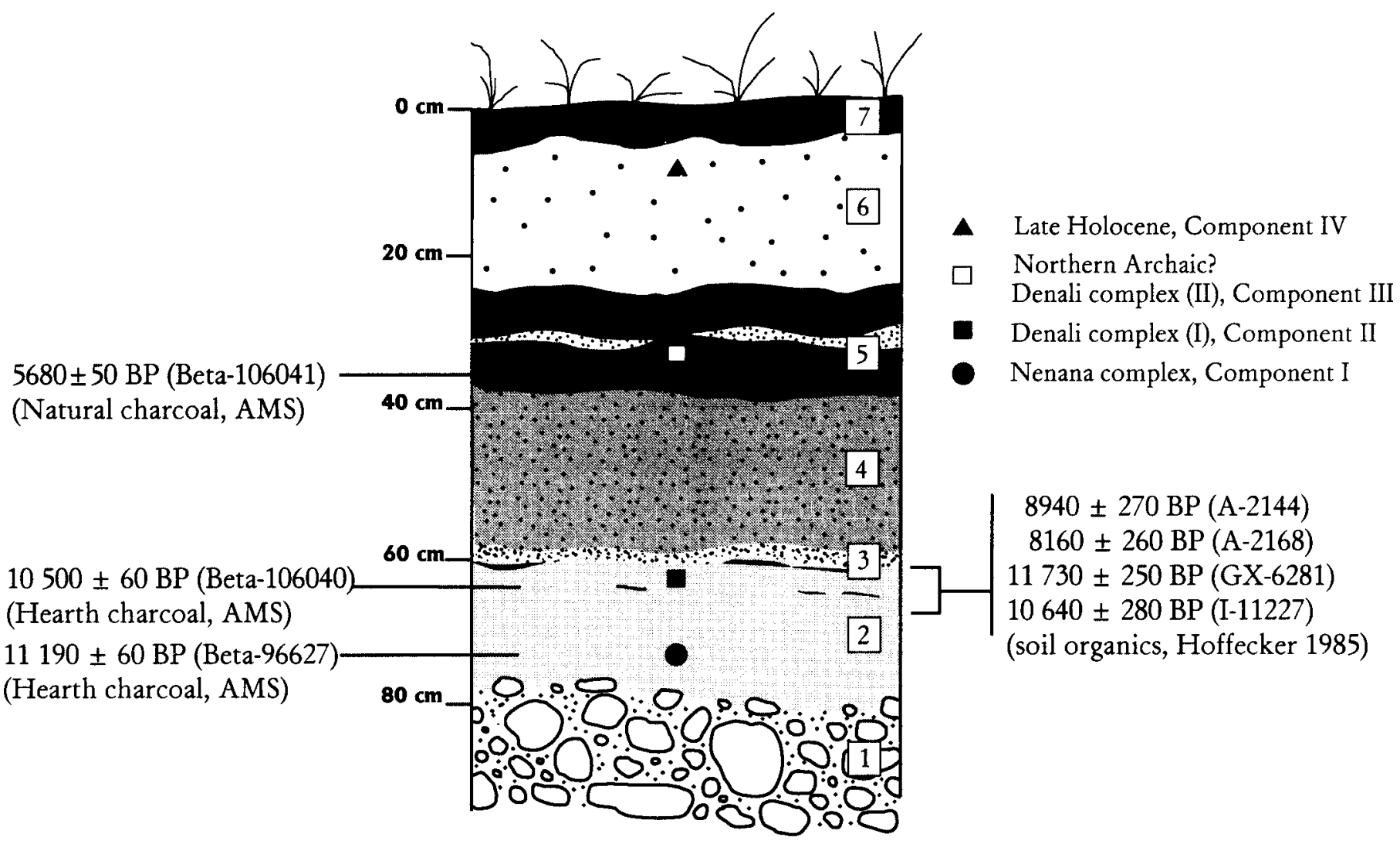

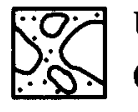

Unit 1

Glacial Outwash

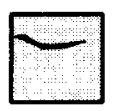

Unit 2

Loess with

Paleosol Stringers
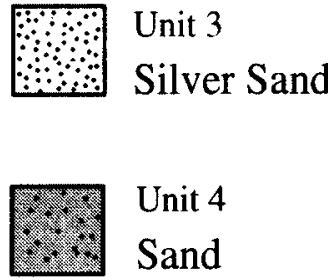



Unit 5

Buried Forest Soils and Sand Lenses

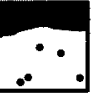

Unit 6, Unit 7

Sandy Loam, Humic Horizon

FIG. 2. Generalized stratigraphic profile of the Moose Creek site, accompanied by radiocarbon dates. The site is composed of seven distinct stratigraphic units and contains four superimposed cultural components.

TABLE 1. Stratigraphic units at the Moose Creek Site.

\begin{tabular}{|c|c|c|}
\hline Stratigraphic Unit & Average Thickness of Deposit & Description \\
\hline Unit 7 Modern O-A-E Horizons & $5-7 \mathrm{~cm}$ & Surface litter and humic layer. \\
\hline Unit 6 Modern B Horizon & $15-20 \mathrm{~cm}$ & Lightly weathered sandy loam. Subarctic Brown Forest soil (cryochrept). \\
\hline Unit 5 Buried Forest Soil complex & $15-20 \mathrm{~cm}$ & $\begin{array}{l}\text { Buried reddish-brown B horizons that are inter-fingered with thin lenses of } \\
\text { sand. The eolian sediments composing this unit are highly weathered and } \\
\text { contain numerous pieces of charcoal. }\end{array}$ \\
\hline Unit 4 Sand & $25-30 \mathrm{~cm}$ & $\begin{array}{l}\text { Homogeneous, golden coloured (weathered), sand layer. A paleosol } \\
\text { stringer is present in the upper part of this unit. }\end{array}$ \\
\hline Unit 3 Silver Sand & $5 \mathrm{~cm}$ & $\begin{array}{l}\text { Light coloured fine sand layer. This unit does not appear to extend over } \\
\text { the entire hilltop. }\end{array}$ \\
\hline Unit 2 Lower Loess with Paleosol Stringers & $25-30 \mathrm{~cm}$ & $\begin{array}{l}\text { Fine wind-blown silt. This unit appears as a massive, tan-coloured } \\
\text { package and does not contain charcoal. Faint discontinuous paleosol } \\
\text { stringers are present in its upper section. Paleosols are better expressed and } \\
\text { more numerous on top of the hill. }\end{array}$ \\
\hline Unit 1 Outwash Gravels & $? \mathrm{~m}$ & $\begin{array}{l}\text { This glacial deposit is a mix of sand, pebbles, and cobbles of various } \\
\text { lithologies. }\end{array}$ \\
\hline
\end{tabular}




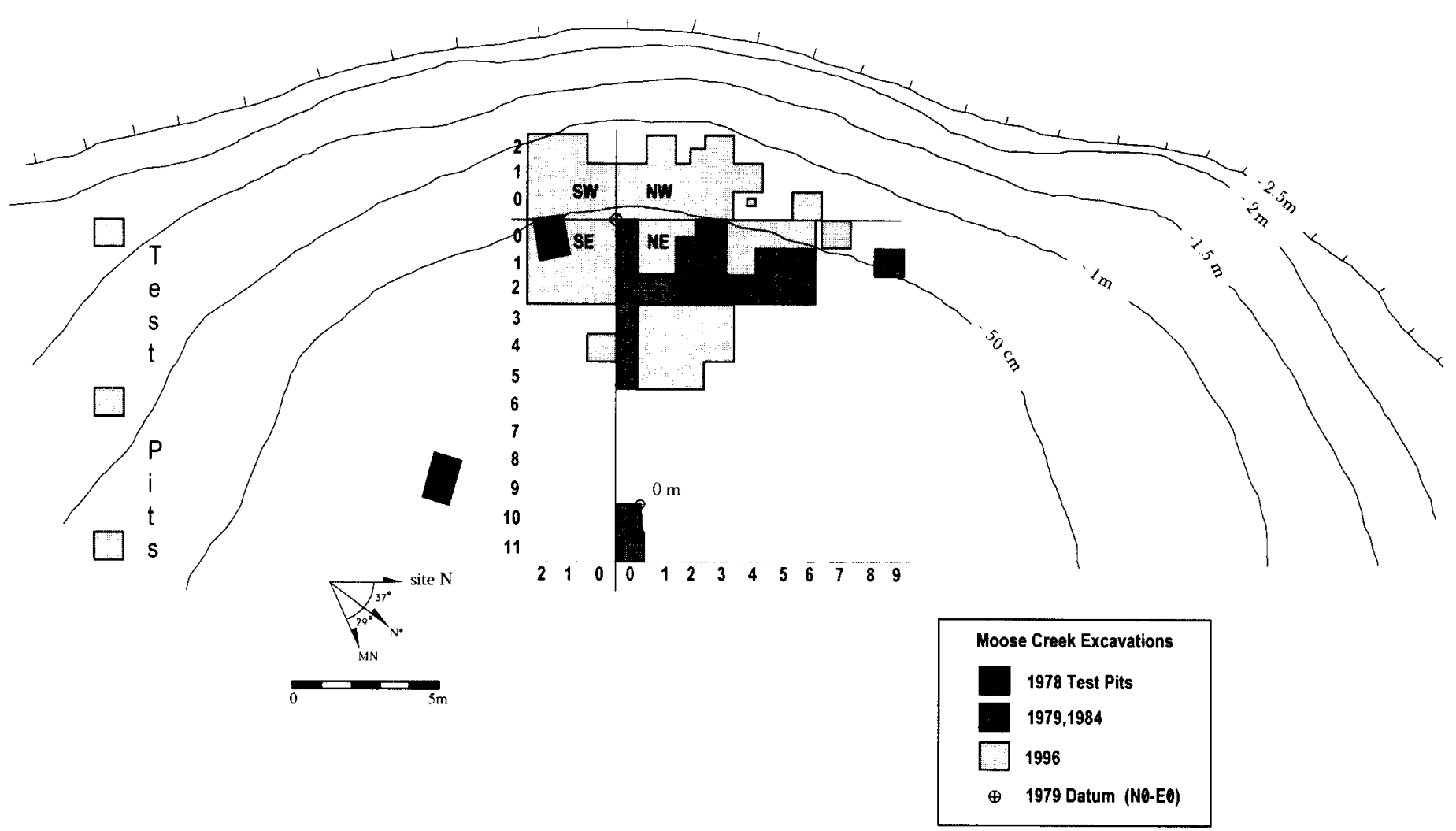

FIG. 3. Location of 1978 test pits and areas excavated between 1979 and 1996 at the Moose Creek Site.

thermokarst feature, and a possible ice wedge were observed during the 1996 excavation. Evidence of significant erosion caused by mass wasting was also noted on the south face of the bluff, in the broken, stair-step topography of its incline and the presence of numerous parallel pressure-release fissures in test pits. To this day, a large, unvegetated scar is present on the south face of the hill, and gravel from the unconsolidated outwash still tumbles down the slope.

\section{EXCAVATION METHOD}

Contiguous units were excavated simultaneously to expose ancient living surfaces and detect signs of possible dwellings like those proposed by Goebel and Powers (1989). Over $45 \mathrm{~m}^{2}$ were excavated around the 1979-84 units, following the original grid system (Fig. 3). This method allowed us to plot new and previous finds and features on a single, comprehensive map.

Since Hoffecker's excavations had unearthed only a dozen flakes above the sand layer (Hoffecker, 1985), Stratigraphic Units 4 to 6 were shovel-skimmed following $10 \mathrm{~cm}$ vertical increments. Artifacts from these upper levels were either three-point provenienced or recorded horizontally by $50 \mathrm{~cm}^{2}$. Sediments from these units were sifted using both $1 / 8$ and $1 / 4$ inch screens.

Stratigraphic Units 2 and 3 were excavated by trowel and were sifted exclusively with $1 / 8$ inch screens. All artifacts below the sand were three-point provenienced,

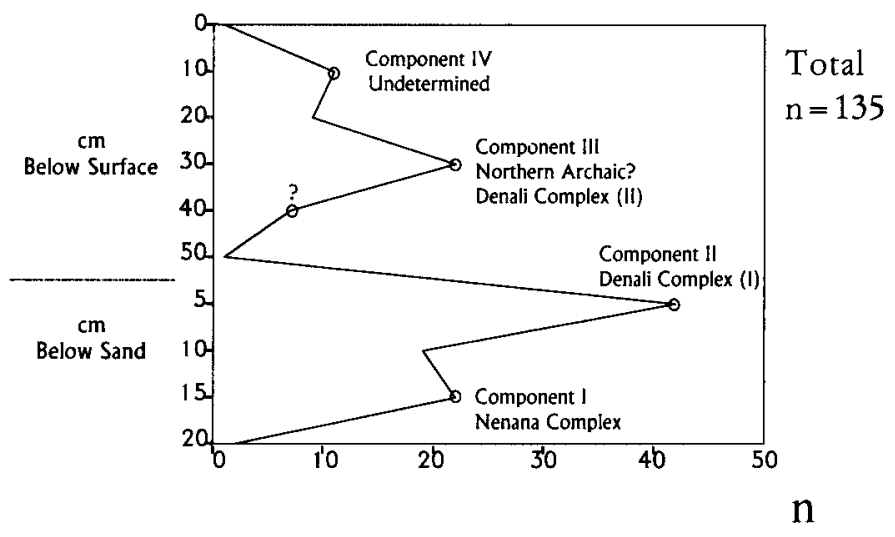

FIG. 4. Vertical distribution of tools from Moose Creek, with four separate peaks representing cultural components I through IV.

and depth was measured using three different methods: below surface, below datum, and below sand. This last method standardized depth measurements and increased the resolution of the arbitrary $5 \mathrm{~cm}$ digging increments by minimizing the distorting effects of slope and unequal thickness of deposits. This standardization permitted us to compare the relative depth of objects found in Unit 2 more readily and accurately.

In addition to the formal excavation, several test pits were dug off site around the main occupation and in other areas of high potential (Figs. 1 and 3). Unfortunately, these exploratory units were either sterile or artifact-poor. No other late Pleistocene-early Holocene occupation was discovered. 


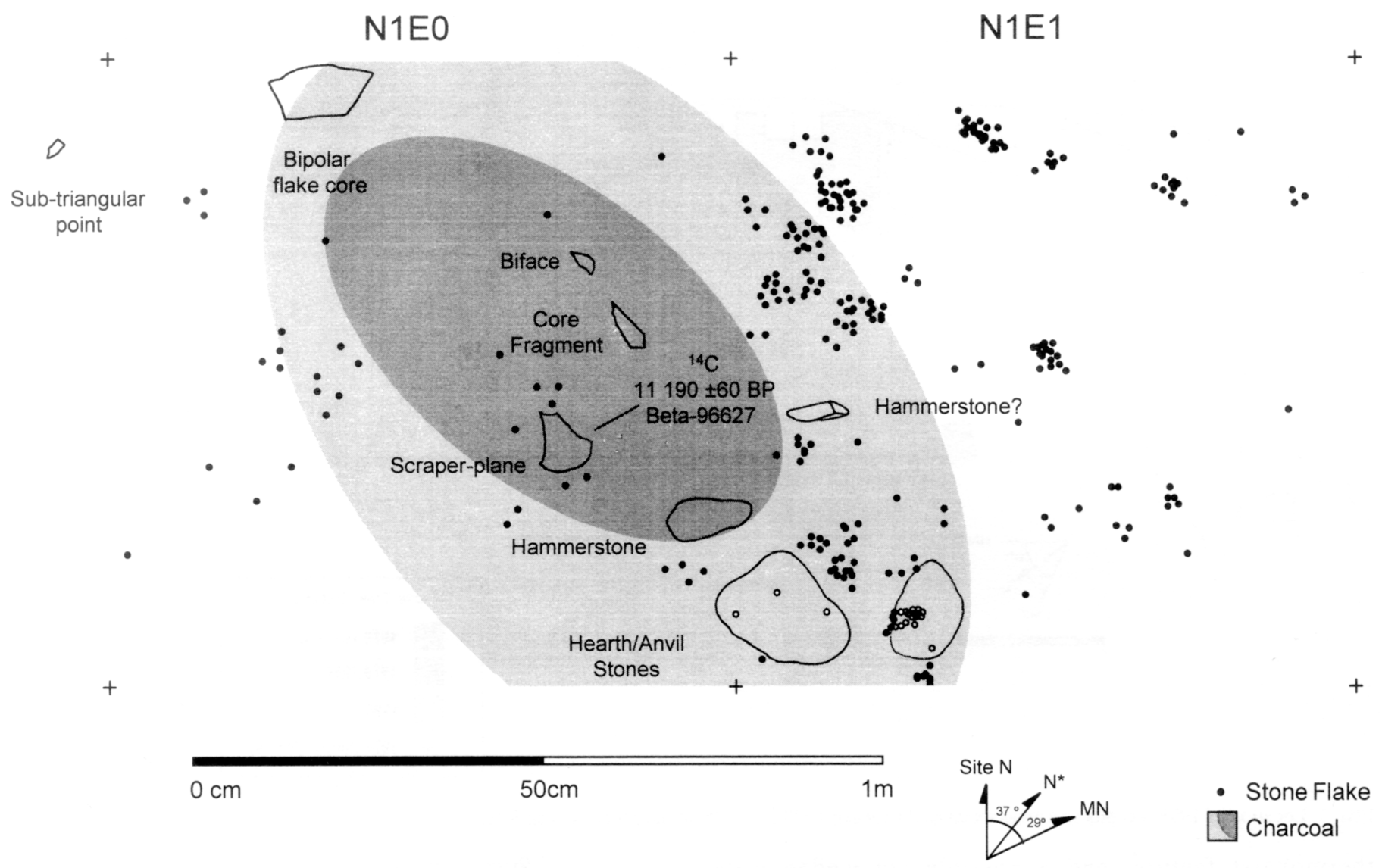

FIG. 5. Nenana complex hearth dated at $11190 \pm 60{ }^{14} \mathrm{C}$ yr BP with flake scatter and associated tools.

\section{CULTURAL COMPONENTS}

Two previously unrecognized cultural components were identified during the re-excavation. Hoffecker's (1985) components I and II were each subdivided stratigraphically, bringing the total to four superimposed occupations. Figure 4 presents the vertical distribution of tools associated with the four components.

\section{Component I}

This lowermost component represents a Nenana complex occupation. It was discovered in Stratigraphic Unit 2 lying approximately $5 \mathrm{~cm}$ above the outwash gravels. Paleosol stringers were not associated with this occupation. A hearth discovered at this level provided wood charcoal used to date the occupation directly (see below). Associated with this feature was an extensive flake scatter, two large cobbles, two side scrapers, a biface, a scraperplane, a flake core, a hammerstone, and a subtriangular point (Figs. 5 and 6). This complete point measures $26 \mathrm{~mm}$ long, $27 \mathrm{~mm}$ wide, and $2 \mathrm{~mm}$ thick. The majority of the artifacts around the hearth were manufactured from a single large core made on a basalt cobble taken from the underlying terrace gravels. Pitting on the large stones and scar patterns on the exhausted core suggest that the basalt cobble was reduced using a bipolar technique and the stones were used as anvils. The hammerstone's extremities are battered, and several parallel striations are visible on its surface. These lines may have resulted from grinding and strengthening of platform edges during tool manufacture. A diagnostic teardrop-shaped Chindadn point, made of nonlocal, purplish-red chert, was also discovered approximately $2 \mathrm{~m}$ from the hearth in Unit SOE1 (Fig. 6e). It measures $34 \mathrm{~mm}$ long, $25 \mathrm{~mm}$ wide, and $4 \mathrm{~mm}$ thick. Faunal remains were not recovered from the Nenana occupation. We must assume that either taphonomic processes are responsible for the scarcity of bones (Guthrie, 1983), or that none were brought to the site.

\section{Component II}

This second component, located in the upper section of Stratigraphic Unit 2, represents a Denali complex occupation belonging to the Paleoarctic tradition (designated here as Denali I). It is associated with the paleosol underlying the sand deposit of Stratigraphic Unit 3. Diagnostic artifacts include 27 microblades manufactured on a single blue chert and a Donnelly burin (Fig. 7h) as defined by West (1981). The microblades were found in a tight cluster, which suggests that they are manufacturing by-products (Pearson, 1996). Although microblade cores and platform rejuvenation tablets were not discovered, several microblade 

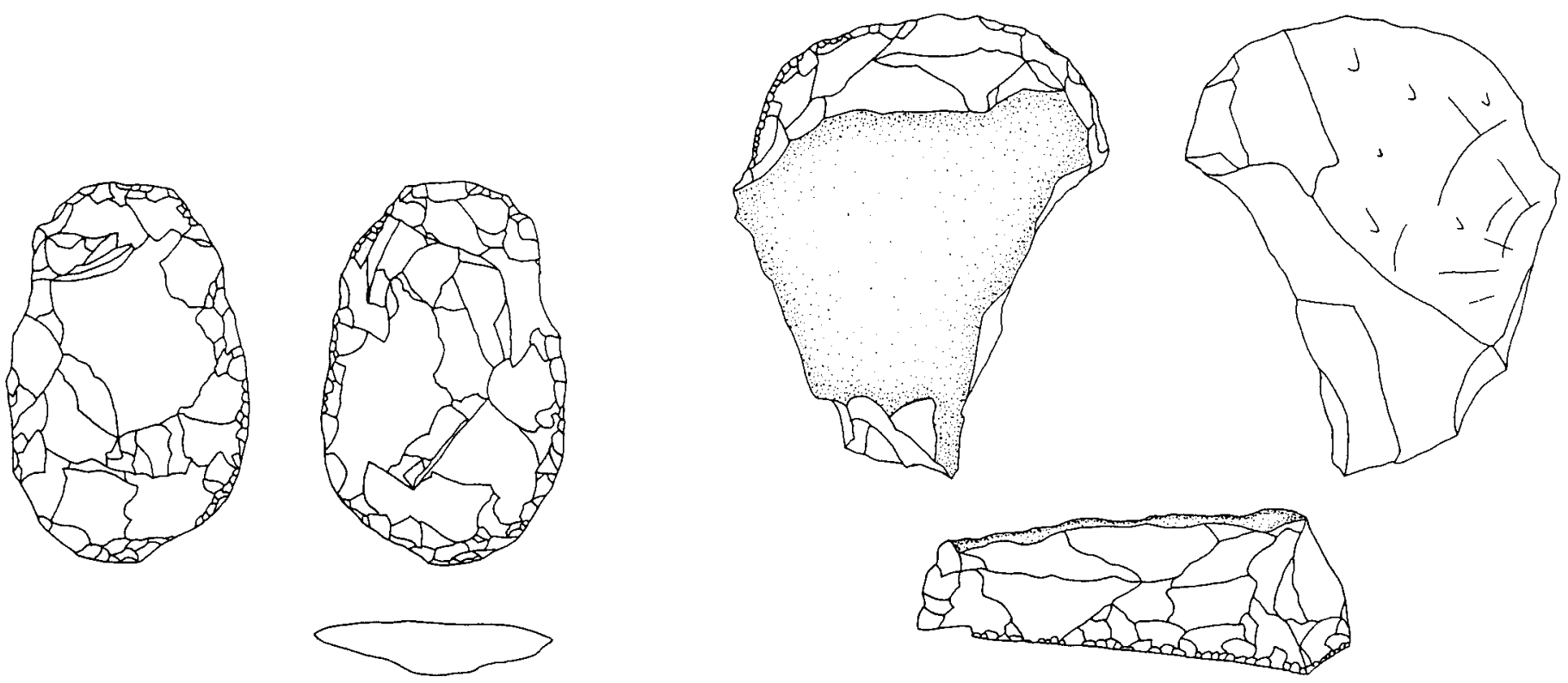

a

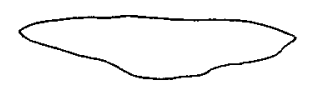

b
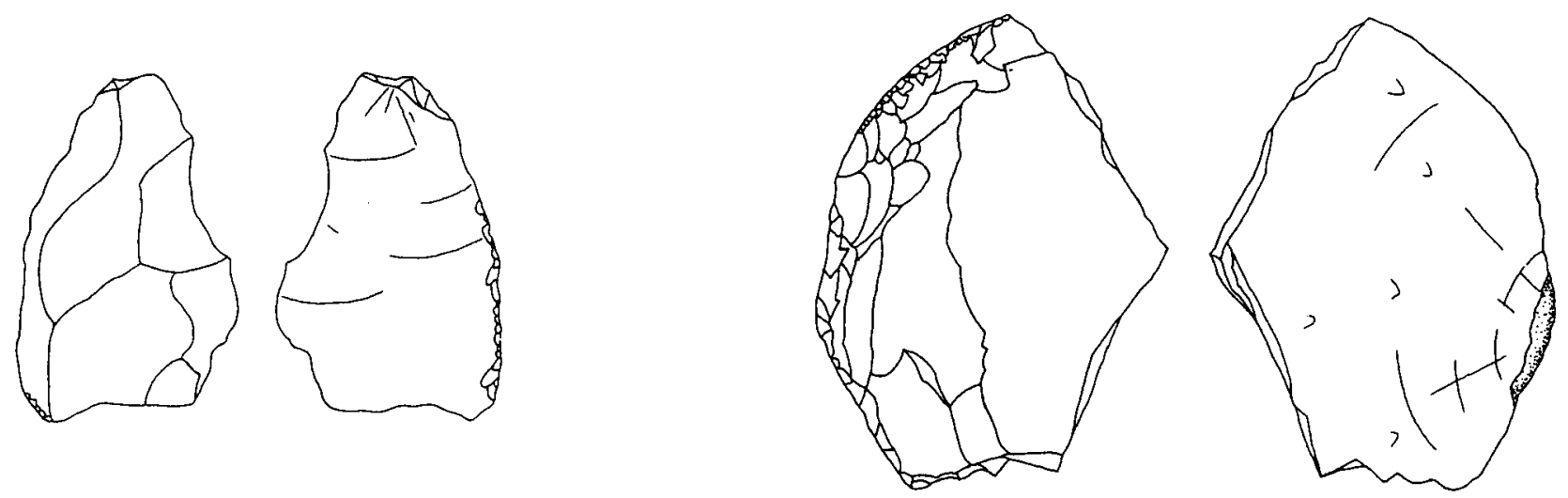

C

d

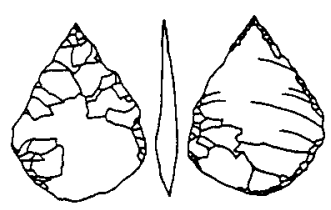

e

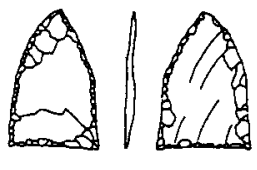

f

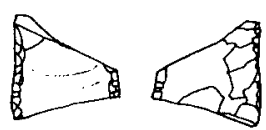

g

FIG. 6. Nenana complex artifacts, Component I: Biface (a), scraper-plane (b), retouched flake (c), side scraper (d), Chindadn point (e), sub-triangular point (f), midsection of possible triangular point discovered in 1979 (\#UA79-155-47, Hoffecker, 1982) (g). 

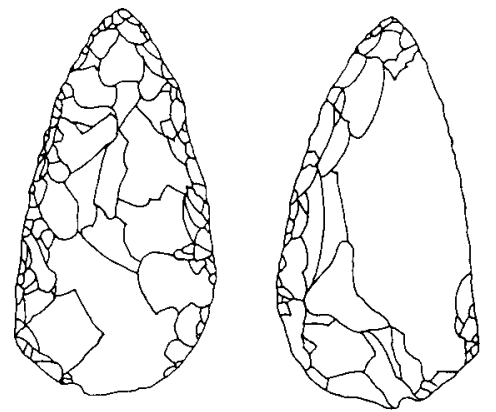

a

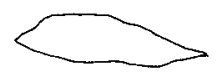

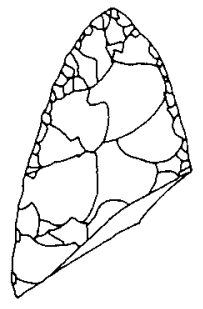

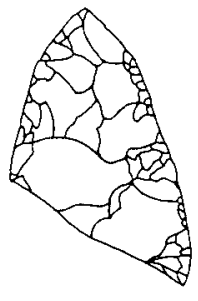

b
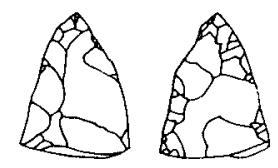

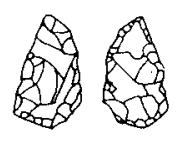

C
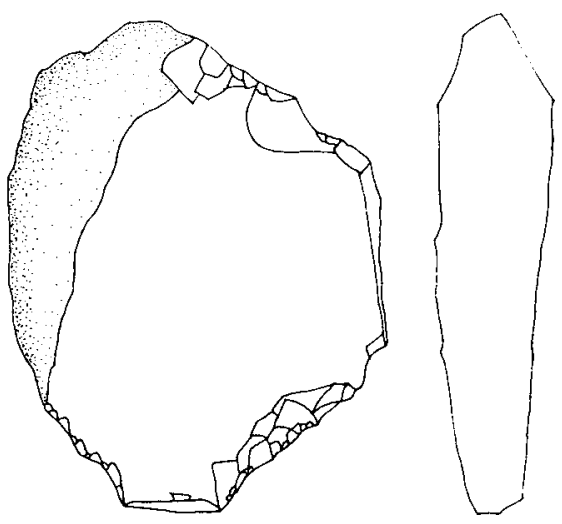

g

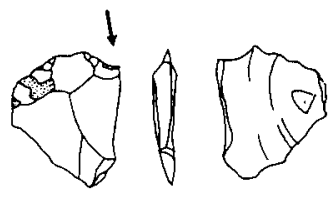

h f

e
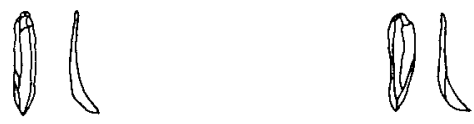

j

i

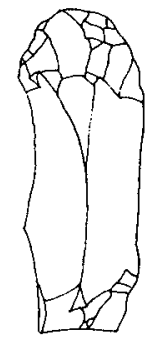

FIG. 7. Denali complex I artifacts, Component II: Bifaces (a-c), lanceolate point bases (d-e), point tip (f), chopper-like spall (g), Donnelly burin (h), microblade overshots (i-j), blade (k).

overshots indicate that the core had a wedge-shaped, fluted face. Additional objects from this level include several complete and fragmented bifaces, a blade, and lanceolate projectile point tips and bases (Fig. 7). The points have diamond-shaped cross-sections, heavily ground bases, and flat proximal ends. A flake scatter and an exhausted core made of gray-white rhyolite were found associated with a hearth containing firecracked rock. Charcoal from this feature was submitted for dating (see below).

\section{Component III}

This component was discovered among the buried forest soil bands overlying the sand in Stratigraphic Unit 5. Cultural material was concentrated between 25 and $35 \mathrm{~cm}$ below the surface. Diagnostic artifacts discovered within the paleosols include microblades and a microblade core rejuvenation tablet (Fig. 8c). On the basis of this evidence, this component appears to represent a second, Holocene-phase Denali complex occupation (hereafter designated as Denali II). 


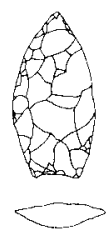

a

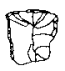

d

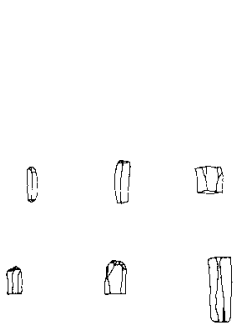

b

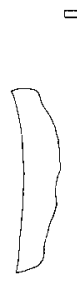

e

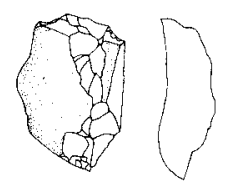

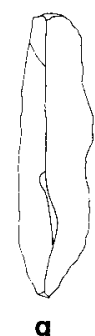

g

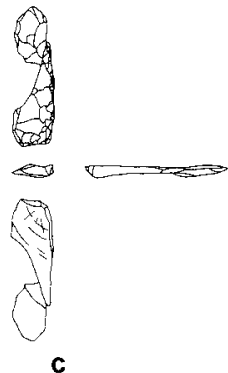

FIG. 8. Denali complex II artifacts, Component III: Projectile point (a), microblades (b), microblade core rejuvenation tablet (c), spurred end scraper (d), double end scraper (e), end scraper (f), blade (g).

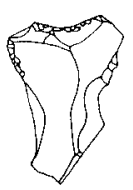

a
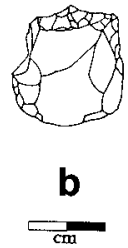

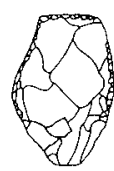

C
FIG. 9. Component IV artifacts: Concave end scraper (a), graver (b), retouched flake (c).

A complete Northern Archaic-like projectile point (see Anderson, 1988:80) made of basalt was also recovered (Fig. 8a). It measures $57 \mathrm{~mm}$ long, $28 \mathrm{~mm}$ wide, and $7 \mathrm{~mm}$ thick. Component III at Moose Creek may be related to Component IV at the Dry Creek site, believed to represent a Northern Archaic occupation (Powers et al., 1983). Dry Creek Component IV did not contain microblades, but it did have waisted points with concave bases that resembled the one recovered at Moose Creek (Powers et al., 1983:379, Fig. C.1, A-D). Other tools found in this component include end scrapers, a blade, and a broken lanceolate projectile point preform (Fig. 8). Hearths and other features were not observed at this level.

\section{Component IV}

The youngest component consists mostly of manufacturing detritus made of milky white rhyolite transported to the site from an unknown primary source. Over 11000 flakes were found dispersed in thick concentrations 0-20 $\mathrm{cm}$ below the surface in Stratigraphic Units 6 and 7. The only tools recovered from this level consist of amorphous and highly battered flake cores, biface fragments, a side scraper, and a graver (Fig. 9). A microblade fragment

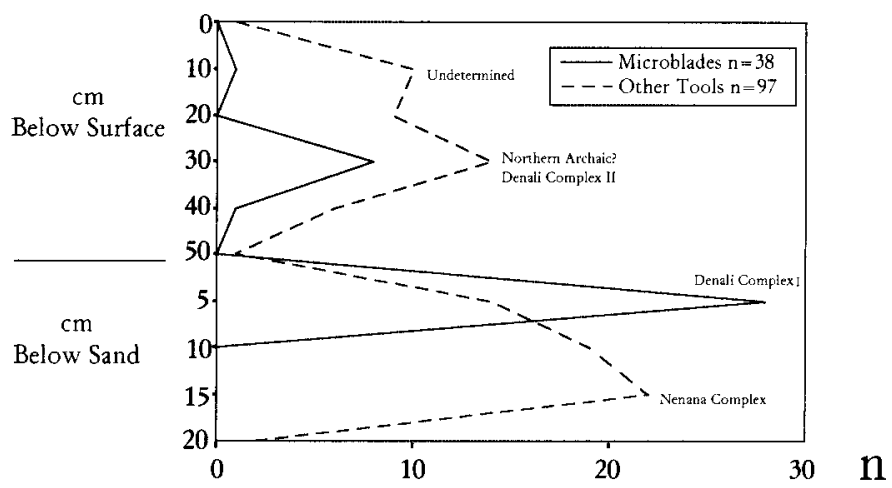

FIG. 10. Comparison between the vertical distribution of microblades and that of all other tools.

( $3 \mathrm{~cm}$ below surface, Fig. 10) and several other artifacts that were found within a loose layer of backfill covering the site are not considered part of this cultural component. A concentration of charcoal associated with a large cobble and a small accumulation of calcined bone was discovered in this component. Unfortunately, the charcoal has not been dated and the bones were too fragmented to determine the elements and species represented. The cultural affiliation of Component IV is undetermined.

\section{RADIOCARBON DATES AND CONTEXT}

Three new radiocarbon dates, measured by accelerator mass spectrometry (AMS), were obtained during the Moose Creek restudy. The measurements for components I and II were derived from charcoal recovered in hearth features, while that for Component III came from a sample collected at the base of Stratigraphic Unit 5. Table 2 presents all three dates accompanied by their stratigraphic positions and cultural affiliations.

The Nenana complex hearth consisted of chunks and bits of burned willow (Salix spp.) concentrated among the basalt lithic scatter. The loess surrounding the charcoal was reddened and slightly indurated. Since neither paleosol stringers nor charcoal was present at this depth, there is no doubt as to the anthropogenic origin of this feature. The $11190 \pm 60{ }^{14} \mathrm{C}$ yr BP (Beta-96627) was measured from a chunk of charcoal found in contact with the scraper plane (Fig. 5). It is interesting to note that the large cobbles found next to the hearth also served as worktables (Binford, 1983:149, 1989:147).

The hearth feature from the Denali I occupation was also associated with a core and a flake scatter. It contained firecracked rock and a large amount of charcoal. The feature was located in Unit SOE4 and continued into the unexcavated western wall of the pit. In stratigraphic profile, the hearth measured $49 \mathrm{~cm}$ long and $3 \mathrm{~cm}$ thick. A charcoal sample collected from the densest part of the feature yielded an AMS date of $10500 \pm 60{ }^{14} \mathrm{C} \mathrm{yr} \mathrm{BP}$ (Beta-106040). Once more, this exceptional, tightly concentrated charcoal was clearly the result of human activity and was quite distinct from the thin and discontinuous purplish paleosol stringers from this level. 
TABLE 2. New AMS dates from the Moose Creek site.

\begin{tabular}{|c|c|c|c|c|c|c|}
\hline Date Uncal. BP & Date Cal. BP (1 sigma) & Lab No. & Material & Stratigraphic Unit & Cultural Component & Cultural Complex \\
\hline $5680 \pm 50$ & $6497-6411$ & Beta-106041 & Natural Charcoal? & 5 & III & Denali complex II \\
\hline $10500 \pm 60$ & $12514-12315$ & Beta- 106040 & Hearth Charcoal & 2 & II & Denali complex I \\
\hline $11190 \pm 60$ & $13179-13097$ & Beta-96627 & Hearth Charcoal & 2 & I & Nenana complex \\
\hline
\end{tabular}

The youngest date of $5680 \pm 50{ }^{14} \mathrm{C}$ yr BP (Beta-106041) was measured from a piece of charcoal collected from the east wall of Unit S1E2. This sample was located in the buried forest soil, slightly above the underlying sand of Unit 4.

\section{DISCUSSION}

\section{Moose Creek and the Validity of the Nenana Complex}

The first humans to inhabit the Nenana Valley were non-microblade users of the Nenana complex. Their lithic industry is characterized by finely crafted, small triangular and teardrop-shaped (Chindadn) points, as well as large cobble tools and scraper-planes (Goebel, 1990; Higgs, 1994). The belief that the Nenana complex represents a separate population unrelated to microblade-using Paleoarctic groups (Haynes, 1982; Goebel et al., 1991; Hoffecker et al., 1993; Pearson, 1997) is further supported at Moose Creek. This techno-cultural dichotomy is observed on Figure 10, which superimposes the vertical distribution of microblades and their manufacturing by-products to that of all other tools. Clearly, the lowest component at Moose Creek lacks microblades.

It is important to note that during the excavation of the basal loess, a $50 \mathrm{~cm}^{2}$ witness column was left unexcavated (Unit S1E0) after the microblade concentration was discovered on its surface. We hoped that this strategy would help us to visualize stratigraphic differences between diagnostic tools, in the event that more were discovered. The Chindadn point (Unit S0E1) and a large cortical piece of the basalt core (Unit S1E0) associated with the Nenana hearth were subsequently discovered $15 \mathrm{~cm}$ below the surface of this column.

Although initial dating at Moose Creek (Hoffecker, 1982) suggested that a pre-Nenana complex might exist, no such evidence was discovered during the re-excavation. The $11190{ }^{14} \mathrm{C}$ yr BP hearth discovered below the paleosol thought to be as old as $11730{ }^{14} \mathrm{C}$ yr BP demonstrates the dangers of using soil organics to date human occupations (Geyh et al., 1971; Polach and Costin, 1971; Gilet-Blein et al., 1980; Head et al., 1989). Statistical tests, using the CALIB 3.0.3 radiocarbon calibration program (Stuiver and Reimer, 1993), demonstrate that Nenana complex radiocarbon dates from the entire valley are contemporaneous and average $11177 \pm 52{ }^{14} \mathrm{C}$ yr BP (Table 3, 13 242-12 944 cal yr BP 2 $\sigma$ ). This mean excludes the initial $11820 \pm 200{ }^{14} \mathrm{C}$ yr BP (Beta-11254) date from Hearth 1 at the Walker Road site on the basis that it is statistically different from two subsequent AMS dates (AA-1681 and AA-1683) measured on the same feature (Goebel et al., 1996).

If we compare the earliest Nenana complex dates measured from hearth charcoal and animal bones (Table 3) from the Nenana Valley to the Broken Mammoth site in the Tanana Valley (Holmes, 1996), we find that they are statistically the same. But the Broken Mammoth dates have a slightly older average of $11329 \pm 44{ }^{14} \mathrm{C}$ yr BP (Table $3 ; 13410-13102$ cal yr BP $2 \sigma$ ). Although these new groupings of dates do not exclude the possibility that the Nenana and Tanana Valleys were inhabited earlier, they provide a more reliable chronology for some of the cultural activities carried out at these sites, since they are derived from anthropogenic charcoal and the remains of meals.

\section{Denali I: The Spread of Microblades in the Nenana Valley}

Approximately 300 to 1000 cal BP years later (Fig. 11), a second group of humans equipped with a microblade technology spread into the Nenana Valley. Moose Creek is unique in that it contains both a late Pleistocene and a Holocene microblade component, separated by a layer of culturally sterile sand. Although both types of microblade industries were known to exist in the Nenana Valley prior to the Moose Creek re-excavation (Powers and Hoffecker, 1989; Goebel and Bigelow, 1992), Holocene and preHolocene assemblages had never been found at a single site, superimposed in a stratified context. The $10500{ }^{14} \mathrm{C}$ yr BP date from the Denali I hearth at Moose Creek supports the previous estimates of $10615 \pm 100$ (AA$11728)$ and $10690 \pm 250(\mathrm{SI}-1561){ }^{14} \mathrm{C}$ yr BP for the early microblades at Dry Creek (Bigelow and Powers, 1994).

\section{Denali II: The Mesoglacial Reoccupation of the Nenana Valley?}

The $5680{ }^{14} \mathrm{C}$ yr BP date for Component III at Moose Creek does not give a direct age for the second microblade assemblage, since it was measured from charcoal of undemonstrated cultural origin. If both microblade occupations at Moose Creek belong to the same cultural group, is it reasonable to postulate that the site was completely abandoned between 10500 and $5680{ }^{14} \mathrm{C}$ yr BP? Or is this apparent cultural hiatus of 6000 calendrical years an artifact of the radiocarbon dating?

I believe an earlier date for Component III would be stratigraphically more sound considering that it overlays the sand deposits of Units 3 and 4 . This sand is $1 \mathrm{~m}$ thick 
TABLE 3. Nenana Complex radiocarbon dates from the Nenana and Tanana Valleys.

\begin{tabular}{|c|c|c|c|c|c|}
\hline Site & Lab No. & ${ }^{14} \mathrm{C}$ Date & Cal. BP (2 sigma) & Material & Reference \\
\hline Moose Creek & Beta-96627 $7^{1}$ & $11190 \pm 60$ & 13 269-12945 & Hearth charcoal & This report \\
\hline Dry Creek & SI-2880 & $11120 \pm 85$ & $13235-12840$ & Natural charcoal? & Hoffecker et al. 1996 \\
\hline Walker Road & Beta-11254 & $11820 \pm 200$ & $14331-13311$ & Hearth 1 charcoal & Goebel et al. 1996 \\
\hline Walker Road & AA- $1681^{1}$ & $11170 \pm 180$ & $13482-12722$ & Hearth 1 charcoal & Goebel et al. 1996 \\
\hline Walker Road & AA- $1683^{1}$ & $11010 \pm 230$ & $13407-12458$ & Hearth 1 charcoal & Goebel et al. 1996 \\
\hline Walker Road & AA-2264 ${ }^{1}$ & $11300 \pm 120$ & $13510-12953$ & Hearth 2 charcoal & Goebel et al. 1996 \\
\hline Broken Mammoth & WSU-4351 & $11770 \pm 210$ & $14287-13243$ & Natural charcoal? & Holmes 1996 \\
\hline Broken Mammoth & WSU-4364 & $11770 \pm 220$ & $14311-13224$ & Natural charcoal? & Holmes 1996 \\
\hline Broken Mammoth & CAMS- $8261^{1}$ & $11500 \pm 80$ & $13682-13212$ & Hearth charcoal & Holmes 1996 \\
\hline Broken Mammoth & WSU-4262 ${ }^{1}$ & $11510 \pm 120$ & $13768-13155$ & Swan bone & Holmes 1996 \\
\hline Broken Mammoth & CAMS-5358 ${ }^{1}$ & $11420 \pm 70$ & $13563-13152$ & Hearth charcoal & Holmes 1996 \\
\hline Broken Mammoth & UGA-6257D & $11280 \pm 190$ & $13636-12808$ & Natural charcoal? & Holmes 1996 \\
\hline
\end{tabular}

${ }^{1}$ Date associated with cultural activity.

Contemporaneous at $95 \%$ level Moose Creek, $11190 \pm 60$ (Beta-96627)

Dry Creek, $11120 \pm 85$ (SI-2880)

Walker Road, $11010 \pm 230$ (AA-1683)

Walker Road, $11170 \pm 180$ (AA-1681)

Walker Road, $11300 \pm 120$ (AA-2264)
Contemporaneous at $95 \%$ level

Moose Creek, $10500 \pm 60$ (Beta-106040)

Dry Creek, $10690 \pm 250$ (SI-1561)

Dry Creek, $10615 \pm 100$ (AA-11728)

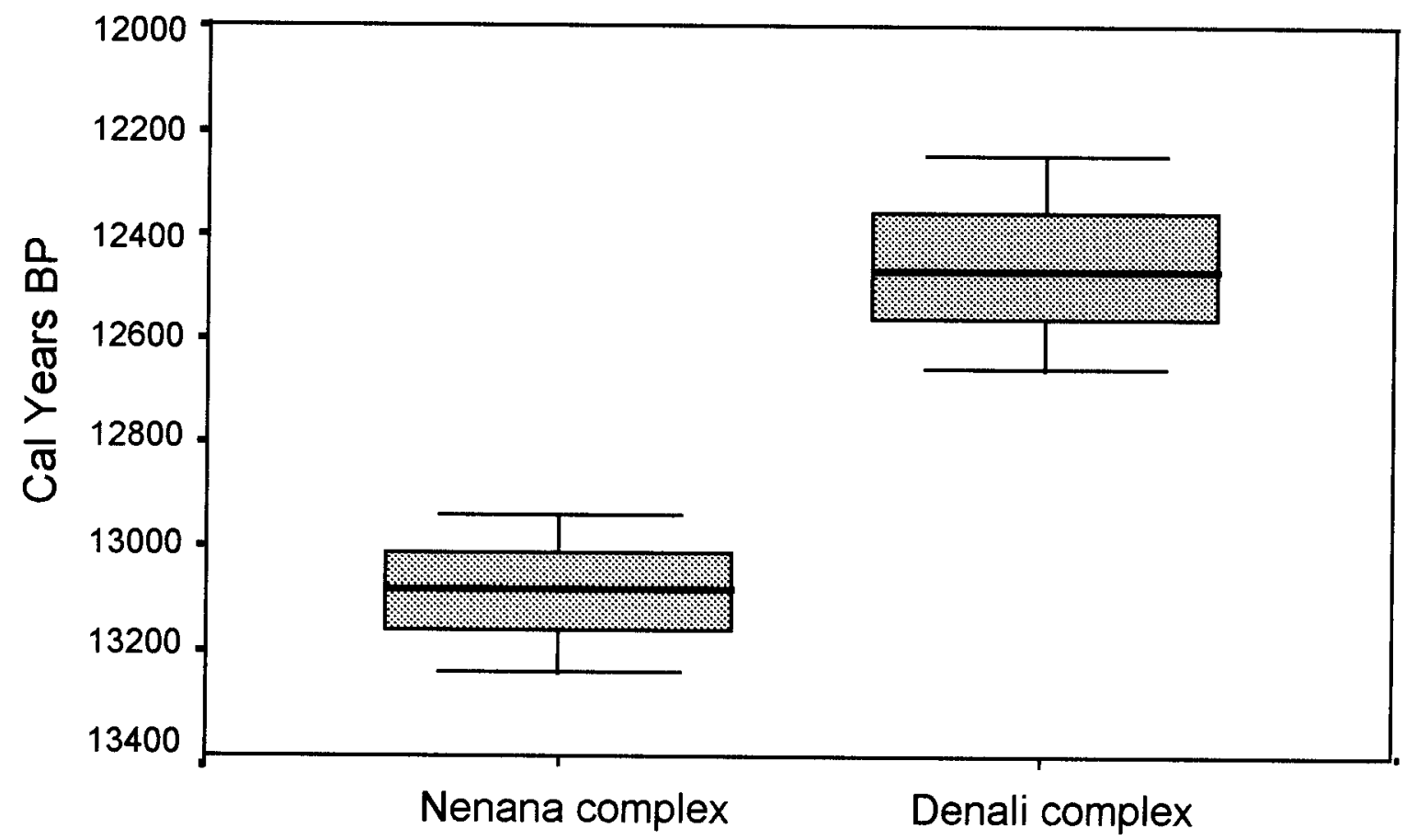

FIG. 11. Average dates (two sigma) for the oldest sites in the Nenana Valley, showing the chronological difference between the Nenana and Denali complex occupations.

in some areas of the site (Hoffecker, 1985) and was probably blown from an unvegetated scarp of the terrace and redeposited on top of the hill. Interestingly, the base of Stratigraphic Unit 3 marks the beginning of the Younger Dryas interval $\left(10600-9500{ }^{14} \mathrm{C}\right.$ yr BP, Johnsen et al., 1992; Björck et al., 1996), believed to be responsible for the late Pleistocene sand sheets in the Nenana Valley (Bigelow et al., 1990). It also correlates with the brief climatic reversal of the McKinley Park IV Stade (MP-IV, 10500 to $9500{ }^{14} \mathrm{C}$ yr BP), as described by Ten Brink and Waythomas (1985). Perhaps the deterioration of tempera- ture associated with the MP-IV Stade was sufficient to denude the Moose Creek hillside of vegetation and expose the underlying outwash to the wind. Under these conditions, the very qualities that made Moose Creek an attractive locale on the landscape, namely its openness and high elevation, may have deterred humans from occupying it during windy episodes. At any rate, it is unlikely that the sand sheet at Moose Creek represents an eolian accumulation of over 6000 solar years, and it is doubtful that the organic stringer found in the upper part of the sand layer accounts for this significant time lapse. 
Since charcoal occurred throughout Stratigraphic Unit 5 , the $5680{ }^{14} \mathrm{C}$-year-old sample, collected below the oldest paleo-Bw Horizon, is probably intrusive and reflects an expanding forest suffering from periodic fires (Thorson and Hamilton, 1977; Powers et al., 1983). Although the artifacts in Component III were found in a complex of buried forest soils, they are not necessarily contemporaneous with the development of those soils or with the deeprooted trees that grew and burned on their surfaces. Thus, the 5680-year-old charcoal sample should not be automatically interpreted as a baseline date for the onset of loess deposition above the sand or for the re-occupation of the site.

Calibration of 67 radiocarbon dates indicates that Holocene Denali complex occupations in central Alaska peaked between 8500 and $8000 \mathrm{cal}$ yr BP (Mason et al., n.d.). This correlates with the cold, dry climate of the Mesoglacial (Beget, 1983; Alley et al., 1997) and a decrease in spruce in the region (Ager, 1983, 1985; Ten Brink and Waythomas, 1985; Edwards and Barker, 1994). Falling within this interval are four radiocarbon assays from Component II at the Panguingue Creek site, located approximately $18 \mathrm{~km}$ south of Moose Creek. These dates were measured on cultural charcoal recovered from a buried forest soil (Goebel and Bigelow, 1996) in a stratigraphic position comparable to the one containing Moose Creek's Component III. All five dates from Panguingue Creek average $7711 \pm 97{ }^{14} \mathrm{C}$ yr BP $(8651-$ $8319 \mathrm{cal}$ yr BP $2 \sigma$; Goebel and Bigelow, 1992) and may represent a more valid age for the microblades in Component III at Moose Creek.

The apparent reoccupation of the Nenana Valley during the Mesoglacial suggests that the Denali economy may not have changed significantly during the Holocene, as groups remained on the periphery of the encroaching boreal forest. Paleoarctic bands may have followed caribou herds pushed north by invading spruce, only to make southern incursions in colder times. It is perhaps during these occasions that Holocene Denali complex hunters encountered Northern Archaic groups believed to have spread from the south (Dumond, 1977; Workman, 1978; Betts, 1987). However, many archaeologists have defended the co-occurrence of Denali and Northern Archaic traits within single occupations (Cook and Gillispie, 1986; Holmes, 1986; Morrison, 1987; Clark, 1992). The question that is posed is whether this co-occurrence represents technological change within Denali populations over time, be it through independent invention or diffusion, or two culturally distinct groups occupying the same region consecutively or synchronically. Consequently, the co-occurrence of microblades and side-notched points at some sites in the Interior may be explained by either a technological amalgamation (Morrison, 1987; Clark, 1992) between these groups or by similar land-use patterns that left palimpsests of multicultural deposits at particular locales. Since the Northern Archaic-like point from Moose Creek was discovered at $20-30 \mathrm{~cm}$ below surface, approximately $10 \mathrm{~cm}$ above the core tablet illustrated in Figure 8c, it is possible that Component III is composed of several chronologically distinct occupations. However, it would be imprudent to further subdivide this component until a more detailed analysis is completed and additional radiocarbon dates are available.

\section{Role of the Moose Creek Site}

Although the Moose Creek re-excavation demonstrates that the sequence and composition of its cultural components are similar to those of other sites in the Nenana Valley, important differences remain. Among the most significant is the site's great elevation above the valley floor that provides an unobstructed view of the entire southern half of the Nenana Valley and the Chicken Creek drainage to the east. The site may have been a strategic overlook used to locate and anticipate the movements of game. Unlike Dry Creek and Walker Road, Moose Creek was not a seasonal camp. Although hearth features were found, no evidence of permanent dwellings was discovered. Moose Creek was perhaps a satellite lookout for a larger occupation situated on a lower terrace nearby. In Component IV, the high ratio of manufacturing detritus to formal tools made from non-local lithic raw material indicates that Moose Creek also served as an important off-quarry reduction area in more recent times.

Another intriguing difference is that the occupation faces west rather than south. However, the absence of cultural material on the southern side of the hill might be more apparent than real, since this part of the summit suffered from mass wasting over the years, possibly as a result of tectonic activity (Thorson and Hamilton, 1977). It is safe to assume that early humans also deposited material on the southern tip of the Moose Creek hilltop, but the evidence was destroyed by erosion.

\section{CONCLUSION}

The Moose Creek re-excavation shows that its sequence of archaeological components is similar to those already observed at other Nenana Valley sites, including Dry Creek (Hoffecker et al., 1996), Walker Road (Goebel et al., 1996; Powers et al., 1990) and Panguingue Creek (Goebel and Bigelow, 1996). This study not only confirmed the existence of a Nenana complex occupation at Moose Creek, but also identified two previously unrecognized microblade components.

The Nenana complex occupation is characterized by an extensive flake scatter and tools associated with a hearth dated to $11190{ }^{14} \mathrm{C}$ yr BP. The majority of these artifacts were made from a large basalt cobble procured from the outwash gravels that compose the underlying terrace. This fact supports evidence from other Nenana complex sites in the Nenana and Tanana Valleys which demonstrates that this early lithic industry incorporated many expedient uses 
of local secondary-source lithic raw materials (Powers and Hoffecker, 1989; Higgs, 1994; Holmes, 1996). Moose Creek is also the first site in the Nenana Valley where both Nenana complex point types, i.e., triangular and teardropshaped, co-occur.

Results from the Moose Creek re-excavation further demonstrate that the Nenana and Denali complexes are chronologically, stratigraphically, and technologically distinct in the Nenana Valley. Chronostratigraphic evidence supports the notion that the first occupants of the Nenana Valley did not manufacture microblades (Goebel et al., 1991). Microblade industries and lanceolate bifacial projectile points appear later in the record. Even at the two-sigma range, radiocarbon dates for the Nenana and Denali complexes show no overlap (Fig. 11). Statistical tests demonstrate that the earliest radiocarbon dates for Nenana complex occupations in the Nenana Valley are contemporaneous and average c. $11200{ }^{14} \mathrm{C}$ yr BP.

The microblade occupations at Moose Creek occur stratigraphically below and above the Pleistocene-Holocene boundary. The oldest was discovered in a fine loess just below a sand layer and contained a hearth dated to $10500{ }^{14} \mathrm{C}$ yr BP. The presence of microblades below this sand indicates that previous archaeological collections (Hoffecker, 1985) were a combination of Denali and Nenana complex materials. The second microblade component is located above the sand, concentrated between 25 and $35 \mathrm{~cm}$ below the surface, in a complex of buried forest soils that provided charcoal dated to $5680{ }^{14} \mathrm{C}$ yr BP. On the basis of the stratigraphic sequence at Moose Creek and the cultural radiocarbon dates from the Panguingue Creek site located in a similar paleosol, the age for the microblades in Component III might be closer to $8000-7000{ }^{14} \mathrm{C}$ yr BP. This period appears to mark a reoccupation or intensified use of the Nenana Valley and correlates with the Mesoglacial climatic reversal (Beget, 1983; Mason et al., n.d.). On the other hand, the presence of a Northern Archaic-like projectile point, found between $20-30 \mathrm{~cm}$ below surface, suggests that an additional mid-Holocene component might be present at Moose Creek. However, it is impossible to determine if this tentative Northern Archaic occupation is, in fact, associated with the microblades until we ascertain the extent to which cryoturbation and bioturbation may have affected the upper part of the site (e.g., using refit studies).

The Moose Creek re-excavation demonstrates how interpretation problems can occur as a result of site sampling errors. This is important at a time of ongoing debates over the validity of certain late Pleistocene cultures in Alaska considered separate from the Paleoarctic tradition (Yesner, 1996), such as the Nenana and Mesa complexes (Kunz and Reanier, 1995). In some cases, the simple presence or absence of microblades should not be the sole criterion by which to determine the cultural affiliations of lithic assemblages. This is especially true considering that microblades discovered at the Swan Point site in the Tanana Valley have been dated to $11600{ }^{14} \mathrm{C}$ years $\mathrm{BP}$ (Holmes et al.,
1996; Holmes, 1998; Dilley, 1998). We must also not forget the second important lesson from Moose Creek, which is to recognize that problems can ensue when ages assigned to human occupations are based on charcoal and organic matter collected from paleosols.

\section{ACKNOWLEDGEMENTS}

The logistical challenges of this project were greatly alleviated by the generous help of W. Roger Powers, Robert A. Beckwith, Thomas E. Dilley, David R. Yesner, Jackie Hendrix, DeVere Pieschl, and Bob Stewart. Many thanks go to the people of Ferry and all who participated. I am indebted to John F. Hoffecker for sharing field notes and valuable information about the site. Taxonomic identification of charcoal was graciously provided by Charles E. Holmes and Dave McMahan of the Department of Natural Resources in Anchorage. Special thanks go to Michael L. Kunz and the Bureau of Land Management, Northern Field Office, in Fairbanks for their invaluable assistance. Thoughtful comments were provided by Owen K. Mason, Ted Goebel, and Dyane N. Vigeant, who reviewed early drafts of this report. This research was supported by the University of Alaska Fairbanks Summer Sessions and funded in part by the University of Alaska Museum Geist Fund. I take full responsibility for any errors present in this paper.

\section{REFERENCES}

AGER, T.A. 1983. Holocene vegetational history of Alaska. In: Wright, H.E., Jr., ed. Late-Quaternary environments in the United States. Vol. 2: The Holocene. Minneapolis, Minnesota: University of Minnesota Press. 128-140.

_. 1985. Palynology. National Geographic Society Research Reports 19:11-13.

ALLEY, R.B., MAYEWSKI, P.A., SOWERS, T., STUIVER, M., TAYLOR, K.C., and CLARK, P.U. 1997. Holocene climatic instability: A prominent, widespread event $8200 \mathrm{yr}$ ago. Geology 25:483-486.

ANDERSON, D.D. 1988. Onion Portage: The archaeology of a stratified site from the Kobuk River, northwest Alaska. Anthropological Papers of the University of Alaska 22. Fairbanks, Alaska: University of Alaska Press.

BEGET, J.E. 1983. Radiocarbon-dated evidence of worldwide early Holocene climate change. Geology 11:389-393.

BETTS, R.C. 1987. Archaeological investigations at Butte Lake, Alaska: An inquiry into Alaskan notched point-microblade assemblages. Report to the University of Alaska Museum Geist Fund. Unpubl. paper. Available at the University of Alaska Museum, 907 Yukon Drive, Fairbanks, Alaska 99775-1200, U.S.A.

BIGELOW, N.H., and POWERS, W.R. 1994. New AMS dates from the Dry Creek Paleoindian site, Central Alaska. Current Research in the Pleistocene 11:114-116.

BIGELOW, N., BEGET, J., and POWERS, R. 1990. Latest Pleistocene increase in wind intensity recorded in eolian sediments from Central Alaska. Quaternary Research 34:160-168. 
BINFORD, L.R. 1983. In pursuit of the past: Decoding the archaeological record. London: Thames and Hudson.

. 1989. Debating archaeology. New York: Academic Press.

BJÖRCK, S., KROMER, B., JOHNSEN, S., BENNICKE, O., HAMMARLUND, D., LEMDAHL, G., POSSNERT, G., RASMUSSEN, T.L., WOHLFARTH, B., HAMMER, C.U., and SPURK, M. 1996. Synchronized terrestrial-atmospheric deglacial records around the North Atlantic. Science 274: $1155-1160$.

CLARK, D.W. 1992. The Archaic in the extreme northwest of North America. Revista de Arqueología Americana 5:17-99.

COOK, J.P., and GILLISPIE, T.E. 1986. Notched points and microblades. Paper presented at the 13th Annual Meeting of the Alaskan Anthropological Association, Fairbanks, Alaska, 6-7 March 1986.

DILLEY, T.E. 1998. Late Quaternary loess stratigraphy, soils, and environment of the Shaw Creek Flats Paleoindian sites, Tanana Valley, Alaska. Ph.D. dissertation, Department of Geosciences, University of Arizona, Tucson, Arizona.

DUMOND, D.E. 1977. The Eskimos and Aleuts. London: Thames and Hudson.

EDWARDS, M.E., and BARKER, E.D., Jr. 1994. Climate and vegetation in northeastern Alaska 18,000 yr B.P.-Present. Palaeogeography, Palaeoclimatology, Palaeoecology 109: $127-135$.

GEYH, M.A., BENZLER, J.-H., and ROESCHMANN, G. 1971. Problems of dating Pleistocene and Holocene soils by radiometric methods. In: Yaalon, D.H., ed. Paleopedology: Origin, nature and dating of paleosols. Jerusalem: Israel University Press. 63-75.

GILET-BLEIN, N., MARIEN, G., and EVIN, J. 1980. Unreliability of ${ }^{14} \mathrm{C}$ dates from organic matter of soils. Radiocarbon 22 : 919-929.

GOEBEL, F.E., and POWERS, W.R. 1989. A possible Paleoindian dwelling in the Nenana Valley, Alaska: Spatial analysis at the Walker Road site. Paper presented at the 16th Annual Meeting of the Alaska Anthropological Association, Anchorage, Alaska.

GOEBEL, T. 1990. Early Paleoindian technology in Beringia. M.A. Thesis, Department of Anthropology, University of Alaska Fairbanks.

GOEBEL, T., and BIGELOW, N. 1992. The Denali complex at Panguingue Creek, Central Alaska. Current Research in the Pleistocene 9:15-18.

- 1996. Panguingue Creek. In: West, F.H., ed. American beginnings. Chicago: University of Chicago Press. 366-371.

GOEBEL, T., POWERS, R., and BIGELOW, N. 1991. The Nenana complex of Alaska and the Clovis origins. In: Bonnichsen, R., and Turnmire, K.L., eds. Clovis: Origins and adaptations. Corvallis, Oregon: Center for the Study of the First Americans. 49-79.

GOEBEL, T., POWERS, W.R., BIGELOW, N., and HIGGS, A.S. 1996. Walker Road. In: West, F.H., ed. American beginnings. Chicago: University of Chicago Press. 356-363.

GUTHRIE, R.D. 1983. Paleoecology of the Dry Creek site and its implications for early hunters. In: Powers, W.R., Guthrie, R.D., and Hoffecker, J.F., eds. Dry Creek: Archaeology and paleoecology of a late Pleistocene Alaskan hunting camp. Washington, D.C.: National Park Service. 209-287.

HAYNES, C.V., Jr. 1982. Were Clovis progenitors in Beringia? In: Hopkins, D.M., Matthews, J.V., Jr., Schweger, C.E., and Young, S.B., eds. Paleoecology of Beringia. New York: Academic Press. 383-398.

HEAD, M.J., ZHOU, W., and ZHOU, M. 1989. Evaluation of ${ }^{14} \mathrm{C}$ ages of organic fractions of paleosols from loess-paleosol sequences near Xian, China. Radiocarbon 31:680-696.

HIGGS, A. 1994. Lithic refits at Walker Road: Continuing studies into the Nenana complex of Central Alaska. Current Research in the Pleistocene 11:132-134.

HOFFECKER, J.F. 1982. The Moose Creek Site: An early man occupation in Central Alaska. Unpubl. report to the National Park Service and the National Geographic Society. Available at the Department of Anthropology, University of Alaska Fairbanks, 310 Eielson, Fairbanks, Alaska 99775, U.S.A.

. 1985. The Moose Creek site. National Geographic Society Research Reports 19:33-48.

- 1996. Moose Creek. In: West, F.H., ed. American beginnings. Chicago: University of Chicago Press. 363-366.

HOFFECKER, J.F., POWERS, W.R., and GOEBEL, T. 1993. The colonization of Beringia and the peopling of the New World. Science 259:46-53.

HOFFECKER, J.F., POWERS, W.R., and BIGELOW, N.H. 1996. Dry Creek. In: West, F.H., ed. American beginnings. Chicago: University of Chicago Press. 343-352.

HOFFECKER, J.F., WAYTHOMAS, C.F., and POWERS, W.R. 1988. Late glacial loess stratigraphy and archaeology in the Nenana Valley, Central Alaska. Current Research in the Pleistocene 5:83-86.

HOLMES, C.E. 1974. New evidence of a late Pleistocene culture in Central Alaska: Preliminary investigations at Dry Creek. Paper presented at the 7th Annual Meeting of the Canadian Archaeological Association, Whitehorse, Yukon, March 1974. . 1986. Lake Minchumina prehistory: An archaeological analysis. Aurora, Alaska Anthropological Association Monograph Series 2. Fairbanks, Alaska: Alaska Anthropological Association.

. 1996. Broken Mammoth. In: West, F.H., ed. American beginnings. Chicago: University of Chicago Press. 312-318.

- 1998. New data pertaining to Swan Point, the oldest microblade site known in Alaska. Current Research in the Pleistocene 15:21-22.

HOLMES, C.E., VANDERHOEK, R., and DILLEY, T.E. 1996. Swan Point. In: West, F.H., ed. American beginnings. Chicago: University of Chicago Press. 319-323.

JOHNSEN, S.J., CLAUSEN, H.B., DANSGAARD, W., FUHRER, K., GUNDESTRUP, N., HAMMER, C.U., IVERSEN, P., JOUZEL, J., STAUFFER, B., and STEFFERNSEN, J.P. 1992. Irregular glacial interstadials recorded in a new Greenland ice core. Nature 359:311.

KUNZ, M.L., and REANIER, R.E. 1995. The Mesa site: A Paleoindian hunting lookout in Arctic Alaska. Arctic Anthropology 32:5-30.

MASON, O.K., BOWERS, P.M., and HOPKINS, D.M. n.d. The early Holocene Milankovitch thermal maximum and humans: 
Adverse conditions for the Denali complex of eastern Beringia. Unpublished ms. Available from O.K. Mason, P.O. Box 83734, Fairbanks, Alaska 99708, U.S.A.

MORRISON, D.A. 1987. The middle prehistoric period and the Archaic concept in the Mackenzie Valley. Canadian Journal of Archaeology 11:49-73.

PEARSON, G.A. 1996. When is a microblade not a microblade?: Theoretical implications of a microdebitage analysis from the Broken Mammoth site. Paper presented at the 23rd Annual Meeting of the Alaska Anthropological Association, Fairbanks, Alaska, 4-6 April 1996.

. 1997. Further thoughts on Clovis Old World origins. Current Research in the Pleistocene 14:74-76.

POLACH, H.A., and COSTIN, A.B. 1971. Validity of soil organic matter radiocarbon dating: Buried soils in Snowy Mountains southeastern Australia as example. In: Yaalon, D.H., ed. Paleopedology: Origin, nature and dating of paleosols. Jerusalem: Israel University Press. 89-96.

POWERS, W.R., and HOFFECKER, J.F. 1989. Late Pleistocene settlement in the Nenana Valley, Central Alaska. American Antiquity 54(2):263-287.

POWERS, W.R., GUTHRIE, R.D., and HOFFECKER, J.F. 1983. Dry Creek: Archaeology and paleoecology of a late Pleistocene Alaskan hunting camp. Washington. D.C.: National Park Service.

POWERS, W.R., GOEBEL, F.E., and BIGELOW, N.H. 1990. Late Pleistocene occupation at Walker Road: New data on the central Alaskan Nenana complex. Current Research in the Pleistocene 7:40-43.

STUIVER, M., and REIMER, P.J. 1993. Extended ${ }^{14} \mathrm{C}$ data base and revised CALIB $3.0{ }^{14} \mathrm{C}$ calibration program. Radiocarbon $35: 215-230$.
TEN BRINK, N.W., and WAYTHOMAS, C.F. 1985. Late Wisconsin glacial chronology of the north-central Alaska Range: A regional synthesis and its implications for early human settlements. National Geographic Society Research Reports 19:15-32.

THORSON, R.M., and HAMILTON, T.D. 1977. Geology of the Dry Creek site: A stratified early man site in interior Alaska. Quaternary Research 7:149-176.

WAHRHAFTIG, C. 1958. Quaternary geology of the Nenana River Valley and adjacent parts of the Alaska Range. Professional Papers 293-A. Washington, D.C.: U.S. Geological Survey.

WEST, F.H. 1981. The archaeology of Beringia. New York: Columbia University Press.

. 1996. The archaeological evidence. In: West, F.H., ed. American beginnings. Chicago: University of Chicago Press. $537-559$.

WORKMAN, W.B. 1978. Prehistory of the Aishihik-Kluane area, southwest Yukon Territory. Mercury Series, Archaeological Survey of Canada Paper No. 74. Ottawa: National Museum of Man.

YESNER, D.R. 1996. Human adaptation at the Pleistocene-Holocene boundary (circa 13,000 to 8,000 BP) in eastern Beringia. In: Straus, L.G., Eriksen, B.V., Erlandson, J.M., and Yesner, D.R., eds. Humans at the end of the Ice Age: The archaeology of the Pleistocene-Holocene transition. New York: Plenum Press. 255-276.

YESNER, D.R., HOLMES, C.E., and PEARSON, G.A. 1999. Recent excavations at the Broken Mammoth site, Big Delta, Alaska: Reflections on activity patterning and artifact assemblages. Paper presented at the 26th Annual Meeting of the Alaska Anthropological Association, Fairbanks, Alaska, 1-3 April 1999. 